\title{
Effects of Different Organic Fertilizers on Improving Soil from Newly Reclaimed Land to Crop Soil
}

\author{
Xuqing Li ${ }^{1}$, Yao $\mathrm{Su}^{2}$, Temoor Ahmed ${ }^{3}$, Haiying Ren ${ }^{4}$, Muhammad Rizwan Javed ${ }^{5}$, , Yanlai Yao ${ }^{2}$, Qianli An ${ }^{3}{ }^{(\mathbb{B}}$, \\ Jianli Yan ${ }^{1, *}$ and Bin $\mathrm{Li}^{3, *}$ (D) \\ 1 Institute of Vegetable, Hangzhou Academy of Agricultural Sciences, Hangzhou 310024, China; lixqing@hz.cn \\ 2 Institute of Environment, Resource, Soil and Fertilizer, Zhejiang Academy of Agricultural Sciences, \\ Hangzhou 310021, China; suyao@zaas.ac.cn (Y.S.); yaoyl@zaas.ac.cn (Y.Y.) \\ 3 Institute of Biotechnology, Zhejiang University, Hangzhou 310058, China; temoorahmed@zju.edu.cn (T.A.); \\ an@zju.edu.cn (Q.A.) \\ 4 The Institute of Horticulture, Zhejiang Academy of Agricultural Sciences, Hangzhou 310021, China; \\ renhy@zaas.ac.cn \\ 5 Department of Bioinformatics and Biotechnology, Government College University Faisalabad (GCUF), \\ Allama Iqbal Road, Faisalabad 38000, Pakistan; rizwan@gcuf.edu.pk \\ * Correspondence: yanjianli00@gmail.com (J.Y.); libin0571@zju.edu.cn (B.L.); Tel..+86-571-8898-2412 (B.L.)
}

check for

updates

Citation: Li, X.; Su, Y.; Ahmed, T.; Ren, H.; Javed, M.R.; Yao, Y.; An, Q.; Yan, J.; Li, B. Effects of Different Organic Fertilizers on Improving Soil from Newly Reclaimed Land to Crop Soil. Agriculture 2021, 11, 560. https: //doi.org/10.3390/agriculture 11060560

Academic Editors: Pavel Krasilnikov, Miguel A. Taboada and Amanullah

Received: 16 May 2021

Accepted: 14 June 2021

Published: 18 June 2021

Publisher's Note: MDPI stays neutral with regard to jurisdictional claims in published maps and institutional affiliations.

Copyright: (c) 2021 by the authors. Licensee MDPI, Basel, Switzerland. This article is an open access article distributed under the terms and conditions of the Creative Commons Attribution (CC BY) license (https:/ / creativecommons.org/licenses/by/ $4.0 /)$.

\begin{abstract}
The rapid development of cities in the recent 10 years caused a reduction in the cultivated land area, which only accounts for $14 \%$ of the total land area in China. Land development and reclamation have been regarded as an effective way to compensate farmland occupation. However, most of the newly reclaimed land has poor soil fertility and suitability; in some cases, the production capacity is only $10-30 \%$ of the occupied farmland. In order to ameliorate the soil quality of the newly reclaimed land, this study evaluated the effects of commercial organic fertilizer $(0.75,1.50$, and $\left.2.25 \mathrm{~kg} / \mathrm{m}^{2}\right)$, mushroom residue $\left(1.50,2.25\right.$, and $\left.3.00 \mathrm{~kg} / \mathrm{m}^{2}\right)$, biogas slurry $(150,225$, and $\left.300 \mathrm{~kg} / \mathrm{m}^{2}\right)$, vegetable cake $\left(0.30\right.$ and $\left.0.60 \mathrm{~kg} / \mathrm{m}^{2}\right)$, and chemical compound fertilizer $\left(37.50 \mathrm{~g} / \mathrm{m}^{2}\right)$ on the $\mathrm{pH}$, moisture content and organic matter content (OMC), available phosphate, total nitrogen, alkaline hydrolysis nitrogen, microbial biomass carbon and nitrogen, and number of total bacteria and phosphate-solubilizing bacteria, as well as the growth of maize seedlings. The results from this study indicate that the soil quality (OMC is an indicator) was ameliorated by chemical and organic fertilizers, in particular commercial organic fertilizers, which caused a $9.35-16.35 \%$ increase in moisture content, a $11.56-18.72 \%$ increase in $\mathrm{pH}$, a 1.73-2.15 fold increase in OMC, a $338.44-491.41 \%$ increase in available $\mathrm{P}$, a $36.80-48.14 \%$ increase in total $\mathrm{N}$, a $95.32-128.34 \%$ increase in alkaline hydrolysis N, a $92.57-178.38 \%$ increase in total bacterial numbers, and a 7.57-20.87 fold increase in microbial biomass carbon compared with the control. The pot experiment further indicated that soil amended with commercial organic fertilizers caused a $20.35-30.55 \%$ increase in the height and a $12.50-16.67 \%$ increase in the total dry weight of maize seedlings. In addition, representative strains with the ability to dissolve phosphorus and fix nitrogen were successfully isolated using the culture method, and were then identified based on colony morphological observation and 16S rDNA sequence analysis, which help us to not only understand why organic fertilizer has great effect on soil improvement, but also provides beneficial microbial resources for further study.
\end{abstract}

Keywords: soil fertility; soil organic matter; soil microbe; P-solubilizing bacteria; N-fixing bacteria; identification

\section{Introduction}

As a result of the rapid development in urbanization over the last 10 years, a large number of farmland has been occupied in China, and a decrease in the amount of cultivated land, which is the basic element of agricultural production, is an inevitable trend [1,2]. The cultivated land area only accounts for $14 \%$ of the total land area in China [3]. The reserve 
cultivated land resources are seriously insufficient because of farmland occupation. In order to achieve food security, a balance of occupation and compensation has been proposed in China, while land development and reclamation have been vigorously implemented over the past 10 years [3]. However, there are various problems in the implementation of a balance system of cultivated land occupation and compensation. The main issue is that the quality of the supplementary cultivated land is not consistent with the quality of the occupied cultivated land; for example, Hu et al. [1] reported that the production capacity of some newly reclaimed land is only $10-30 \%$ of the occupied farmland based on the quality investigation of the occupied farmland in Hangzhou of Zhejiang Province in the last five years.

All of the factors affecting the soil's physical, chemical, and biological properties will impact the soil quality [4-6]. Although there are many problems with the newly reclaimed land, a low organic matter content (OMC) is regarded as a main cause for its poor soil quality, which does not completely meet the requirements of a high crop yield. Indeed, the content of organic matter in soil is the basis of soil fertility. On the other hand, newly cultivated land is generally acidic in the south of China, such as in Zhejiang Province, because of the long-term use of chemical fertilizer, and the limited or lack of application of organic fertilizer in recent years, which has caused soil hardening and acidification, decreased soil fertility, poor arable ability, and decreased crop yield [1-3]. Obviously, the $\mathrm{pH}$ value and organic matter content of soil can be adjusted through the application of organic fertilizer.

It is well known that the soil suitability of newly reclaimed land is highly associated with the content of the soil organic matter, which can strengthen the ability of the soil to maintain and supply fertilizer, change the structure of soil aggregates, and enhance soil fertility. Specifically, more and more studies have shown that the quality of newly reclaimed land and the content of soil organic matter could be effectively improved by increasing the use of organic fertilizer, such as planting winter legume crops; returning crop stems and stalks to the field; promoting the use of commercial organic fertilizer; comprehensively utilizing agricultural and animal husbandry wastes; and making compost by using rural litter, other plant residues, and gully soil [7-13]. Therefore, it can be inferred that organic fertilizers are, in general, ideal conditioners for newly reclaimed soil.

The objective of this study is to evaluate the effect of different organic fertilizers on improving the soil quality and plant growth suitability of newly reclaimed land. Furthermore, the number and community of soil bacteria were measured to understand the underlying amelioration of organic fertilizers. In addition, some representative bacterial strains with the ability for $\mathrm{N}$-fixation and $\mathrm{P}$-solubilization were isolated in this study, and were identified based on morphological observation and $16 \mathrm{~S}$ rDNA sequence analysis.

\section{Materials and Methods}

\subsection{Sources of Soils and Organic/Chemical Fertilizers}

The soil type of new reclamation land is acrisols (acidic soils with a layer of clay accumulation), based on the soil classification system of the FAO-UNESCO, while its fertility grade (1-10, with 1 being the best) is grade 3 and class 6 based on the nutrient classification standard of the second soil survey in China. The commercial organic fertilizer, mushroom residue biogas liquid was provided by Chun'an Shicheng Soil Fertilizer Co., Ltd. (Hangzhou, China), while vegetable cake was provided by Hangzhou Academy of Agricultural Sciences, Hangzhou, China. The commercial chemical compound fertilizer (N-P-K, 15-15-15) was purchased from Henan Xinlianxin Chemical Industry Group Co., Ltd. (Xinxiang, China). The $\mathrm{pH}$, composition, and price of each soil amendments used in this study are shown in Table 1. 
Table 1. The $\mathrm{pH}$, composition and price of each soil amendments used in this study.

\begin{tabular}{cccccc}
\hline Amendments & $\mathbf{p H}$ & OMC & NPK Content & Others & Price (CNY/kg) \\
\hline COF & 7.0 & $45.0 \%$ & $10.2 \%$ & amino acids and auxin & 0.65 \\
MR & 7.5 & $92.5 \%$ & $5.4 \%$ & Polysaccharide and auxin & 0.25 \\
BL & 7.3 & $1.1 \%$ & $0.3 \%$ & & \\
VC & 4.3 & $74.0 \%$ & $7.1 \%$ & Ca $(0.9 \%)$ and $\mathrm{Mg}(0.5 \%)$ & 2.40 \\
CCF & 4.5 & & $45.0 \%$ & & 3.50 \\
\hline
\end{tabular}

COF-commercial organic fertilizer; $\mathrm{MR}$ - mushroom residue; BL-biogas liquid; VC—vegetable cake; $\mathrm{CCF}$ chemical compound fertilizer; OMC-organic matter contents; CNY-Chinese yuan.

\subsection{Soil Treatments and Samples Collection}

The field plot experiment (Figure 1) was completely randomly designed in this study. The area of each plot was about $20 \mathrm{~m}^{2}$, while the width and depth of the plot separated by the ditch were $30 \mathrm{~cm}$ and $20 \mathrm{~cm}$, respectively. The experiment consisted of 13 different treatments through the application of various organic/chemical fertilizer to newly reclaimed land. The dosage of each fertilizer was set according to the local farmers' habits, and then fluctuated up and down. In detail, commercial organic fertilizer was applied in concentrations of $0.75,1.50$, and $2.25 \mathrm{~kg} / \mathrm{m}^{2}$; mushroom residue was applied in concentrations of $1.50,2.25$, and $3.00 \mathrm{~kg} / \mathrm{m}^{2}$; biogas slurry was applied in concentrations of 150,225 , and $300 \mathrm{~kg} / \mathrm{m}^{2}$; vegetable cake was applied in concentrations of 0.30 and $0.60 \mathrm{~kg} / \mathrm{m}^{2}$; chemical compound fertilizer was applied in concentrations of $37.50 \mathrm{~g} / \mathrm{m}^{2}$; and treatment without any organic and chemical fertilizer was used as the control. After one year, about $1000 \mathrm{~g}$ fresh weight soil was collected from each treatment. The experiment was repeated twice in an agricultural year and each treatment had three replicates.
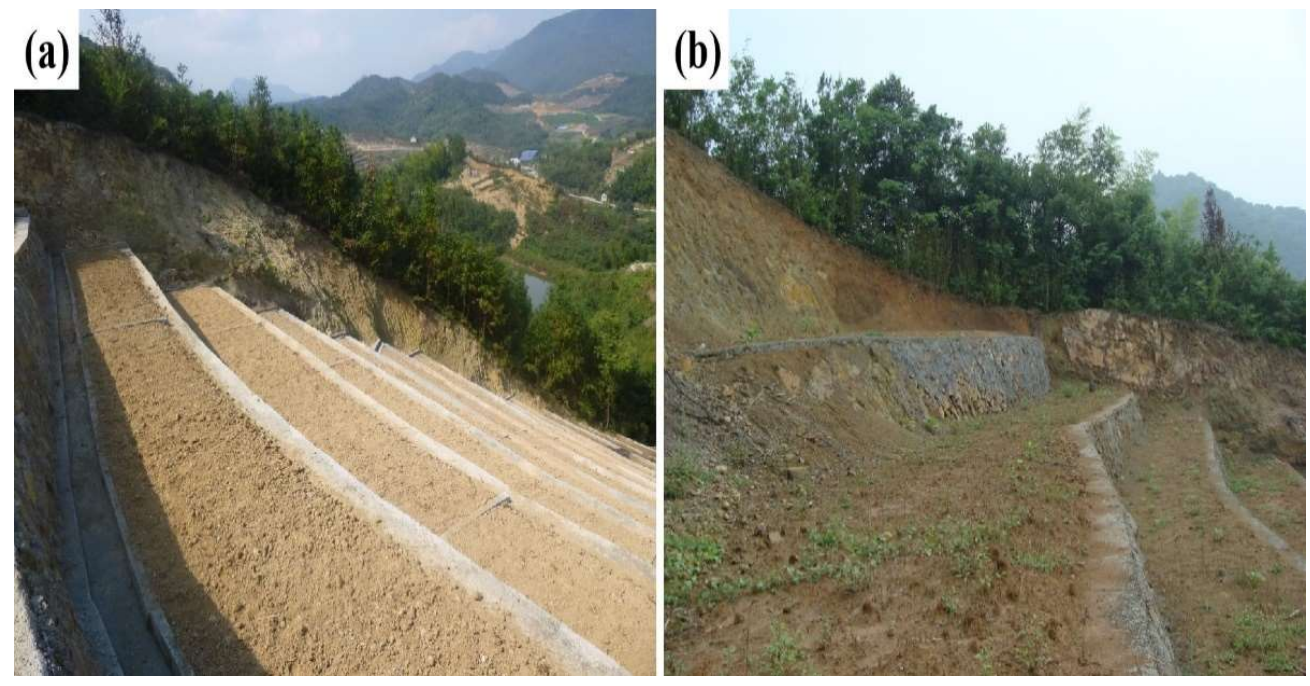

Figure 1. Soil improvement (a) in the newly reclaimed land (b) in Hangzhou. The soil of the new reclamation land is a green-purple mud field with silty clay loam.

\subsection{Measurement of Soil Parameters}

The soil physicochemical properties were determined as described by [14,15]. In brief, the $\mathrm{pH}$ of soil was measured at a soil/distilled water suspension ratio of 1:5 $(\mathrm{g} / \mathrm{mL})$ with a pH meter (FE28, MettlerToledo, Zurich, Switzerland); the soil moisture content was determined by the soil weight before and after the soil was oven dried at $105^{\circ} \mathrm{C}$ for $24 \mathrm{~h}$; the total $\mathrm{N}$ was determined using an automatic Kjeldahl distillation-titration unit; the available $\mathrm{P}$ was determined through sodium bicarbonate extraction and molybdenum blue colorimetry; alkaline hydrolysable nitrogen was assayed using the alkali-hydrolyzed diffusion method; organic carbon was measured using exothermic heating and oxidation with the potassium dichromate method, while conversions between the values of organic carbon and organic matter were made using a Van Bemmelen factor of 1.724; and the soil microbial biomass carbon $(\mathrm{MBC})$ and microbial biomass nitrogen $(\mathrm{MBN})$ were extracted 
using $0.5 \mathrm{~mol} \mathrm{~L}^{-1} \mathrm{~K}_{2} \mathrm{SO}_{4}$, and were then determined by $\mathrm{K}_{2} \mathrm{Cr}_{2} \mathrm{O}_{7}$ oxidation and $\mathrm{FeSO}_{4}$ titration for $\mathrm{MBC}$ and the micro-Kjeldahl method for MBN, respectively.

\subsection{Counting the Number of Total and P-Solubilizing Bacteria}

The soil solutions were prepared by dissolving $10 \mathrm{~g}$ of the collected fresh soils into distilled water, and then filtering with four layers of gauze so as to remove impurities. The total surviving bacterial cells and P-solubilizing bacteria were determined as described by Li et al. [16], by counting colony numbers in a nutrient agar medium and the National Botanical Research Institute's phosphate growth medium [17], respectively. In brief, suspensions of soil microbe were 10 -fold serially diluted and $10 \mu \mathrm{L}$ samples were inoculated on a nutrient agar medium in sextuplicate for each dilution and were incubated for 48 $\mathrm{h}$ at $30^{\circ} \mathrm{C}$. After incubation, the surviving cells on the agar were counted based on the colony-forming units and then the mean value of the cells at the lowest dilution was calculated. This experiment was repeated twice with six replicates for each treatment.

\subsection{Community Structure by $16 S$ rRNA Amplicon Sequencing}

The total genomic DNA was extracted from stool samples using the OMEGA Soil DNA Kit (OMEGA Bio-Tek, Norcross, GA, USA), according to the manufacturer's recommendations. The quantity and quality of the extracted DNA were detected using a NanoDrop ND1000 spectrophotometer (Thermo Fisher Scientific, Waltham, MA, USA) and agarose gel electrophoresis, respectively. The extracted DNA was stored at $-20^{\circ} \mathrm{C}$ until PCR amplifcation and Illumina MiSeq DNA sequencing. The DNA samples were subjected to the first-run PCR reaction using the specified forward primer $338 \mathrm{~F}\left(5^{\prime}\right.$-ACTCCTACGGGAGGCAGCA$\left.3^{\prime}\right)$ and reverse primer 806R ( $5^{\prime}$-GGACTACHVGGGTWTCTAAT-3'), which were designed to amplify the V3-V4 genomics region of the bacterial $16 \mathrm{~S}$ rRNA genes. The PCR system contained $5 \mu \mathrm{L}$ buffer solution $(5 \times), 0.25 \mu \mathrm{L}$ fast pfu DNA polymerase $(5 \mathrm{U} / \mu \mathrm{L}), 2 \mu \mathrm{LdNTPs}$ $(2.5 \mathrm{mM}), 1 \mu \mathrm{L}$ forward and reverse primers $(10 \mu \mathrm{M}), 1 \mu \mathrm{L}$ DNA template solution, and $14.75 \mu \mathrm{L} \mathrm{ddH_{2 }} \mathrm{O}$. The thermal cycle consisted of an initial denaturation of $5 \mathrm{~min}$ at $98^{\circ} \mathrm{C}$, followed by 25 cycles of denaturation at $98^{\circ} \mathrm{C}$ for $30 \mathrm{~s}$, annealing at $53^{\circ} \mathrm{C}$ for $30 \mathrm{~s}$, expansion at $72{ }^{\circ} \mathrm{C}$ for $45 \mathrm{~s}$, and finally an extension of $5 \mathrm{~min}$ at $72{ }^{\circ} \mathrm{C}$. Following confirmation with gel electrophoresis, the PCR amplified products were purified using V azyme VAHTSTM DNA Clean Beads (V azyme, Nanjing, China), and were then subjected to a DNA library preparation according to the $16 \mathrm{~S}$ rRNA Sequencing Library Preparation instructions (Illumina, San Diego, CA, USA). The prepared amplicons were sequenced on the MiSeq platform (Illumina, San Diego, CA, USA) with the MiSeq Reagent Kit v3 (600 cycles) from Shanghai Personal Biotechnology Co., Ltd. (Shanghai, China). The sequence data analysis was carried out as described by Zhang et al. [18] and Brandt and Albertsen [19], with minor modifications, using QIIME2 (version 2020.06) [20] and vegan, ggplot2, pheatmap, ggtree package in R (v3.6.0) [21-24]. In brief, 16S rRNA gene amplicon sequences were demultiplexed and pre-processed. Barcode and primer removal, quality control, amplicon sequence data correction, phiXfltering, and dereplication were verified using the DADA2 software package43 [25]. The structural changes of the microbial community in different samples were investigated.

\subsection{Evaluation for Plant Growth Promotion}

Seeds (cultivar Xiantiannuo911) of maize were sowed in a pot filled with the abovementioned newly reclaimed land, following the improvement of soil quality using chemical and different biological organic fertilizers, while the control was applied without any organic and chemical fertilizers. After emergence, seven seedlings were kept in each pot, which was incubated at $25^{\circ} \mathrm{C}$ with $16 \mathrm{~h}$ daylight and $8 \mathrm{~h}$ night light conditions, and watered daily. The seedlings were harvested after 10 days of emergence, and the height and total dry weight were counted as described by Ali et al. [26]. Each treatment had three pots. 


\subsection{Isolation and Identification of P-Solubilizing and N-Fixing Bacteria}

P-solubilizing bacteria were isolated as described by Masum et al. [27], by streaking soil suspensions on the National Botanical Research Institute's phosphate (NBRIP) growth medium [17]. The medium was supplemented with $5 \mathrm{~g} / \mathrm{L} \mathrm{Ca}_{3}(\mathrm{PO} 4)_{2}$ as a P source. The $\mathrm{pH}$ of the medium was adjusted to 7.0 before autoclaving. After incubating the inoculated plates in the dark at $30{ }^{\circ} \mathrm{C}$ for $48 \mathrm{~h}$, the bacterial isolates with a clear zone (halo) were collected. Furthermore, the nitro-fixation ability of these P-solubilizing bacteria was determined by observing the color change, as described in previous studies [28-31]. In addition, the representative isolates of the P-solubilizing and $\mathrm{N}$-fixing bacteria were identified through an analysis of the $16 \mathrm{~S}$ rDNA sequence, which was carried out as described in our previous studies $[26,27]$.

\subsection{Statics Analysis}

The software STATGRAPHICS Plus, version 4.0 (ManugisticsInc., Rockville, MD, USA) was used to perform the statistical analyses. The levels of significance $(p<0.05)$ of the main treatments and their interactions were calculated through an analysis of variance after testing for normality and variance homogeneity.

\section{Results}

\subsection{Change in the $p H$, Moisture Content and Organic Matters Contents}

The results from this study indicated that the moisture content, $\mathrm{pH}$, and OMC were differentially affected by four kinds of organic fertilizers at different concentrations. The effect was dependent on the soil parameters and the kinds of biological organic fertilizers and their concentration. In detail, the moisture content was significantly increased by commercial organic fertilizer at $0.75,1.50$, and $2.25 \mathrm{~kg} / \mathrm{m}^{2}$; mushroom residue at $1.50 \mathrm{~kg} / \mathrm{m}^{2}$; and vegetable cake at $0.60 \mathrm{~kg} / \mathrm{m}^{2}$, while the moisture content was significantly decreased by the biogas liquid at $300 \mathrm{~kg} / \mathrm{m}^{2}$. There was no significant difference in the moisture content between the other treatments and the control. Furthermore, compared with the control, the $\mathrm{pH}$ was increased for all of the treatments, except there was no change in biogas liquid at $300 \mathrm{~kg} / \mathrm{m}^{2}$, and there was a decrease in vegetable cake at 0.30 and $0.60 \mathrm{~kg} / \mathrm{m}^{2}$, as well as in the chemical compound fertilizer at $37.50 \mathrm{~g} / \mathrm{m}^{2}$. In addition, the content of organic matter was significantly increased by all of the 12 chemical and biological organic fertilizers treatments, with a $7.04-214.50 \%$ increase compared with the control, while the commercial organic fertilizers at three different concentrations showed a $173.29-214.50 \%$ increase in the OMC of new reclamation land (Table 2).

Table 2. Effect of different biological organic and chemical fertilizer on the $\mathrm{pH}$, content of moisture, and organic matter in new reclamation soil.

\begin{tabular}{cccc}
\hline Treatments & Moisture Content (\%) & $\mathbf{p H}$ & Organic Matter Contents (g/kg) \\
\hline COF $\left(0.75 \mathrm{~kg} / \mathrm{m}^{2}\right)$ & $20.79 \pm 0.18 \mathrm{bc}$ & $6.47 \pm 0.03 \mathrm{~b}$ & $39.19 \pm 0.77 \mathrm{~b}$ \\
$\mathrm{COF}\left(1.50 \mathrm{~kg} / \mathrm{m}^{2}\right)$ & $20.47 \pm 0.39 \mathrm{bc}$ & $6.08 \pm 0.05 \mathrm{~d}$ & $39.54 \pm 0.40 \mathrm{~b}$ \\
$\mathrm{COF}\left(2.25 \mathrm{~kg} / \mathrm{m}^{2}\right)$ & $21.78 \pm 0.67 \mathrm{~b}$ & $6.11 \pm 0.02 \mathrm{~d}$ & $45.10 \pm 0.46 \mathrm{a}$ \\
MR $\left(1.50 \mathrm{~kg} / \mathrm{m}^{2}\right)$ & $20.26 \pm 1.14 \mathrm{c}$ & $6.60 \pm 0.02 \mathrm{a}$ & $37.47 \pm 0.37 \mathrm{c}$ \\
MR $\left(2.25 \mathrm{~kg} / \mathrm{m}^{2}\right)$ & $17.85 \pm 0.88 \mathrm{de}$ & $6.49 \pm 0.04 \mathrm{~b}$ & $38.89 \pm 0.12 \mathrm{~b}$ \\
MR $\left(3.00 \mathrm{~kg} / \mathrm{m}^{2}\right)$ & $18.99 \pm 0.21 \mathrm{~cd}$ & $6.38 \pm 0.03 \mathrm{c}$ & $15.55 \pm 0.35 \mathrm{i}$ \\
$\mathrm{BL}\left(150 \mathrm{~kg} / \mathrm{m}^{2}\right)$ & $17.41 \pm 1.70 \mathrm{de}$ & $5.63 \pm 0.03 \mathrm{e}$ & $33.02 \pm 0.12 \mathrm{~d}$ \\
$\mathrm{BL}\left(225 \mathrm{~kg} / \mathrm{m}^{2}\right)$ & $17.38 \pm 0.80 \mathrm{de}$ & $5.57 \pm 0.02 \mathrm{f}$ & $17.92 \pm 0.18 \mathrm{~h}$ \\
$\mathrm{BL}\left(300 \mathrm{~kg} / \mathrm{m}^{2}\right)$ & $16.74 \pm 0.55 \mathrm{e}$ & $5.42 \pm 0.01 \mathrm{~g}$ & $15.35 \pm 0.21 \mathrm{i}$ \\
VC $\left(0.30 \mathrm{~kg} / \mathrm{m}^{2}\right)$ & $18.71 \pm 0.61 \mathrm{~d}$ & $5.34 \pm 0.02 \mathrm{~h}$ & $24.76 \pm 0.28 \mathrm{f}$ \\
VC $\left(0.60 \mathrm{~kg} / \mathrm{m}^{2}\right)$ & $23.79 \pm 1.05 \mathrm{a}$ & $5.18 \pm 0.03 \mathrm{j}$ & $28.19 \pm 0.78 \mathrm{e}$ \\
$\mathrm{CCF}\left(37.50 \mathrm{~g} / \mathrm{m}^{2}\right)$ & $19.12 \pm 0.22 \mathrm{~cd}$ & $5.29 \pm 0.04 \mathrm{i}$ & $19.94 \pm 0.42 \mathrm{~g}$ \\
Control & $18.72 \pm 1.56 \mathrm{~d}$ & $5.45 \pm 0.03 \mathrm{~g}$ & $14.34 \pm 0.31 \mathrm{j}$ \\
\hline
\end{tabular}

COF-commercial organic fertilizer; MR-mushroom residue; BL-biogas liquid; VC—vegetable cake; CCFchemical compound fertilizer. Values followed by different lowercase letters within the same column indicate significant difference at $p<0.05$. 


\subsection{Change in Available $P$, the Total $N$ and Alkaline Hydrolysis $N$}

The result from this study indicated that biological organic fertilizers have a differential effect in the available $\mathrm{P}$, total $\mathrm{N}$, and alkaline hydrolysis $\mathrm{N}$, while the effect was dependent on the soil parameters, as well as the kinds of biological organic fertilizers and its concentration. In detail, compared with the control, the available P was unaffected by biogas liquid at $300 \mathrm{~kg} / \mathrm{m}^{2}$, but was significantly changed by all of the other 11 treatments with a $30.91-491.41 \%$ increase. Furthermore, the total $\mathrm{N}$ was significantly changed by all of the 12 chemical and biological organic fertilizer treatments, with a $6.52-48.14 \%$ increase. In addition, the alkaline hydrolysis $\mathrm{N}$ was unaffected by the biogas liquid at $300 \mathrm{~kg} / \mathrm{m}^{2}$ and the chemical fertilizer at $37.5 \mathrm{~g} / \mathrm{m}^{2}$, but was increased by the other 10 treatments with a $16.98-128.34 \%$ increase (Table 3).

Table 3. Effect of different biological organic fertilizers and chemical fertilizers on the available $\mathrm{P}$, total $\mathrm{N}$, and alkaline hydrolysis $\mathrm{N}$ in new reclamation soil.

\begin{tabular}{cccc}
\hline Treatments & Available $\mathbf{P}(\mathbf{m g} / \mathbf{k g})$ & Total N $\mathbf{g} / \mathbf{k g})$ & AlkalineHydrolysisN $(\mathbf{m g} / \mathbf{k g})$ \\
\hline COF $\left(0.75 \mathrm{~kg} / \mathrm{m}^{2}\right)$ & $118.86 \pm 2.55 \mathrm{~b}$ & $9.54 \pm 0.28 \mathrm{a}$ & $241.22 \pm 9.41 \mathrm{a}$ \\
$\mathrm{COF}\left(1.50 \mathrm{~kg} / \mathrm{m}^{2}\right)$ & $120.80 \pm 1.84 \mathrm{~b}$ & $8.81 \pm 0.23 \mathrm{~b}$ & $211.34 \pm 7.91 \mathrm{~b}$ \\
COF $\left(2.25 \mathrm{~kg} / \mathrm{m}^{2}\right)$ & $160.33 \pm 5.93 \mathrm{a}$ & $9.51 \pm 0.13 \mathrm{a}$ & $247.06 \pm 4.15 \mathrm{a}$ \\
MR $\left(1.50 \mathrm{~kg} / \mathrm{m}^{2}\right)$ & $90.98 \pm 0.86 \mathrm{c}$ & $8.34 \pm 0.30 \mathrm{c}$ & $210.58 \pm 10.75 \mathrm{~b}$ \\
MR $\left(2.25 \mathrm{~kg} / \mathrm{m}^{2}\right)$ & $67.19 \pm 2.27 \mathrm{~d}$ & $8.94 \pm 0.07 \mathrm{~b}$ & $149.76 \pm 5.27 \mathrm{~d}$ \\
MR $\left(3.00 \mathrm{~kg} / \mathrm{m}^{2}\right)$ & $61.21 \pm 1.29 \mathrm{e}$ & $7.71 \pm 0.14 \mathrm{e}$ & $149.90 \pm 6.41 \mathrm{~d}$ \\
BL $\left(150 \mathrm{~kg} / \mathrm{m}^{2}\right)$ & $35.49 \pm 3.72 \mathrm{~g}$ & $8.02 \pm 0.18 \mathrm{~d}$ & $126.57 \pm 6.06 \mathrm{e}$ \\
BL $\left(225 \mathrm{~kg} / \mathrm{m}^{2}\right)$ & $37.27 \pm 3.36 \mathrm{~g}$ & $7.65 \pm 0.06 \mathrm{e}$ & $152.53 \pm 2.25 \mathrm{~d}$ \\
$\mathrm{BL}\left(300 \mathrm{~kg} / \mathrm{m}^{2}\right)$ & $24.54 \pm 5.97 \mathrm{~h}$ & $7.61 \pm 0.10 \mathrm{e}$ & $103.42 \pm 2.94 \mathrm{f}$ \\
VC $\left(0.30 \mathrm{~kg} / \mathrm{m}^{2}\right)$ & $58.94 \pm 1.86 \mathrm{e}$ & $7.19 \pm 0.10 \mathrm{f}$ & $197.81 \pm 3.68 \mathrm{c}$ \\
VC $\left(0.60 \mathrm{~kg} / \mathrm{m}^{2}\right)$ & $62.59 \pm 2.21 \mathrm{de}$ & $7.80 \pm 0.07 \mathrm{de}$ & $189.49 \pm 3.85 \mathrm{c}$ \\
$\mathrm{CCF}\left(37.50 \mathrm{~g} / \mathrm{m}^{2}\right)$ & $53.65 \pm 1.75 \mathrm{f}$ & $6.86 \pm 0.17 \mathrm{~g}$ & $118.01 \pm 12.48 \mathrm{ef}$ \\
Control & $27.11 \pm 1.23 \mathrm{~h}$ & $6.44 \pm 0.06 \mathrm{~h}$ & $108.20 \pm 2.36 \mathrm{f}$ \\
\hline
\end{tabular}

COF-commercial organic fertilizer; MR—-mushroom residue; BL—biogas liquid; VC—vegetable cake; CCFchemical compound fertilizer. Values followed by different lowercase letters within the same column indicate significant difference at $p<0.05$.

\subsection{Change in Total Microbial Biomass Carbon and Nitrogen}

The results from this study indicated that the total MBC and MBN were differentially affected by various kinds of biological organic fertilizers, while the effect was dependent on the microbial parameter, as well as the kinds of biological organic fertilizers and their concentration. In detail, compared with the control, the MBC value was unaffected by the mushroom residue at 2.25 and $3.00 \mathrm{~kg} / \mathrm{m}^{2}$, biogas liquid at 150 and $300 \mathrm{~kg} / \mathrm{m}^{2}$, and chemical fertilizer at $37.50 \mathrm{~g} / \mathrm{m}^{2}$, while the other seven treatments significantly changed the MBC value with a 2.32-20.88-fold increase. Furthermore, the MBN value was unaffected by organic fertilizer at $2.25 \mathrm{~kg} / \mathrm{m}^{2}$ and mushroom residue at $2.25 \mathrm{~kg} / \mathrm{m}^{2}$. However, there was a significant decrease (range of $35.88 \%$ to $64.54 \%$ ) from organic fertilizer at 0.75 and $1.50 \mathrm{~kg} / \mathrm{m}^{2}$, mushroom residue at 1.50 and $3.00 \mathrm{~kg} / \mathrm{m}^{2}$, biogas liquid at 150 and $300 \mathrm{~kg} / \mathrm{m}^{2}$, vegetable cake at $0.60 \mathrm{~kg} / \mathrm{m}^{2}$, and chemical fertilizer at $37.50 \mathrm{~g} / \mathrm{m}^{2}$, while there was a significant increase (2.02-and 3.56-fold) from biogas liquid $225 \mathrm{~kg} / \mathrm{m}^{2}$ and vegetable cake at $0.30 \mathrm{~kg} / \mathrm{m}^{2}$, respectively (Table 4 ).

\subsection{Change in Number of Total and P-Solubilizing Bacteria}

This study indicated that the number of total soil bacteria and P-solubilizing bacteria was affected by various kinds of biological organic fertilizers, while the effect was dependent on the kinds of biological organic fertilizers and its concentration. In detail, compared to the control, there was a significant increase (range, $97.30 \%$ to $178.38 \%$ ) in the number of total soil bacteria by organic fertilizer at 0.75 and $2.25 \mathrm{~kg} / \mathrm{m}^{2}$, mushroom residue at 1.50 and $2.25 \mathrm{~kg} / \mathrm{m}^{2}$, biogas liquid at 225 and $300 \mathrm{~kg} / \mathrm{m}^{2}$, vegetable cake at $0.30 \mathrm{~kg} / \mathrm{m}^{2}$, while the number of total soil bacteria was unaffected by the other treatments. Furthermore, there was a significant increase $(228.57 \%)$ in the number of P-solubilizing bacteria by mushroom 
residue at $1.50 \mathrm{~kg} / \mathrm{m}^{2}$, while the number of P-solubilizing bacteria was unaffected by all the other treatments (Table 4 ).

Table 4. Effect of different biological organic and chemical fertilizer on bacterial numbers and total biomass in new reclamation soil.

\begin{tabular}{|c|c|c|c|c|}
\hline \multirow{2}{*}{ Treatments } & \multicolumn{2}{|c|}{ Bacterial Numbers } & \multicolumn{2}{|c|}{ Total Biomass } \\
\hline & Total $\left(10^{7}\right)$ & PSB $\left(10^{3}\right)$ & MBC (mg/kg) & MBN (mg/kg) \\
\hline COF $\left(0.75 \mathrm{~kg} / \mathrm{m}^{2}\right)$ & $3.48 \pm 1.06 \mathrm{ab}$ & $2.17 \pm 0.98 \mathrm{a}$ & $643.89 \pm 7.66 \mathrm{a}$ & $35.10 \pm 6.93 \mathrm{~d}$ \\
\hline $\operatorname{COF}\left(1.50 \mathrm{~kg} / \mathrm{m}^{2}\right)$ & $2.85 \pm 0.64 \mathrm{bc}$ & $1.57 \pm 0.72 \mathrm{ab}$ & $252.23 \pm 30.86 \mathrm{~d}$ & $19.50 \pm 4.63 \mathrm{~d}$ \\
\hline $\operatorname{COF}\left(2.25 \mathrm{~kg} / \mathrm{m}^{2}\right)$ & $4.12 \pm 0.72 \mathrm{a}$ & $1.77 \pm 0.25 \mathrm{ab}$ & $334.88 \pm 22.11 \mathrm{c}$ & $65.51 \pm 9.82 c$ \\
\hline $\operatorname{MR}\left(1.50 \mathrm{~kg} / \mathrm{m}^{2}\right)$ & $2.92 \pm 0.90 \mathrm{~b}$ & $2.07 \pm 0.25 \mathrm{a}$ & $190.16 \pm 23.01 \mathrm{f}$ & $22.54 \pm 2.82 \mathrm{~d}$ \\
\hline $\operatorname{MR}\left(2.25 \mathrm{~kg} / \mathrm{m}^{2}\right)$ & $3.23 \pm 0.96 \mathrm{~b}$ & $2.03 \pm 0.50 \mathrm{ab}$ & $79.43 \pm 13.21 \mathrm{gh}$ & $50.07 \pm 8.75 \mathrm{~cd}$ \\
\hline $\operatorname{MR}\left(3.00 \mathrm{~kg} / \mathrm{m}^{2}\right)$ & $2.48 \pm 0.62 \mathrm{bc}$ & $1.93 \pm 0.15 a b$ & $80.00 \pm 9.49 \mathrm{gh}$ & $35.26 \pm 2.85 \mathrm{~d}$ \\
\hline $\mathrm{BL}\left(150 \mathrm{~kg} / \mathrm{m}^{2}\right)$ & $1.65 \pm 0.73 c$ & $0.67 \pm 0.21 \mathrm{~b}$ & $47.07 \pm 6.49 \mathrm{hi}$ & $25.59 \pm 6.53 \mathrm{~d}$ \\
\hline BL $\left(225 \mathrm{~kg} / \mathrm{m}^{2}\right)$ & $3.05 \pm 0.41 \mathrm{~b}$ & $1.03 \pm 0.15 \mathrm{~b}$ & $222.78 \pm 8.38 \mathrm{e}$ & $165.92 \pm 26.91 \mathrm{~b}$ \\
\hline $\mathrm{BL}\left(300 \mathrm{~kg} / \mathrm{m}^{2}\right)$ & $3.02 \pm 0.56 \mathrm{~b}$ & $1.30 \pm 0.10 \mathrm{~b}$ & $54.50 \pm 8.16 \mathrm{~h}$ & $26.36 \pm 3.40 \mathrm{~d}$ \\
\hline $\mathrm{VC}\left(0.30 \mathrm{~kg} / \mathrm{m}^{2}\right)$ & $3.93 \pm 0.68 \mathrm{ab}$ & $0.77 \pm 0.06 \mathrm{~b}$ & $526.46 \pm 20.17 b$ & $250.62 \pm 12.86 \mathrm{a}$ \\
\hline $\mathrm{VC}\left(0.60 \mathrm{~kg} / \mathrm{m}^{2}\right)$ & $2.10 \pm 0.33 c$ & $0.90 \pm 0.03 \mathrm{~b}$ & $97.79 \pm 10.65 \mathrm{~g}$ & $24.64 \pm 4.00 \mathrm{~d}$ \\
\hline $\operatorname{CCF}\left(37.50 \mathrm{~g} / \mathrm{m}^{2}\right)$ & $2.45 \pm 0.38 \mathrm{bc}$ & $1.43 \pm 0.64 \mathrm{ab}$ & $23.66 \pm 10.13 \mathrm{i}$ & $26.53 \pm 1.15 \mathrm{~d}$ \\
\hline Control & $1.48 \pm 0.37 \mathrm{c}$ & $0.63 \pm 0.12 b$ & $29.43 \pm 5.97 \mathrm{hi}$ & $54.99 \pm 5.05 c$ \\
\hline
\end{tabular}

COF-commercial organic fertilizer; MR-mushroom residue; BL-biogas liquid; VC-vegetable cake; CCFchemical compound fertilizer. PSB - phosphate-solubilizing bacteria. MBC - microbial biomass carbon; MBNmicrobial biomass nitrogen. Values followed by different lowercase letters within the same column indicate significant difference at $p<0.05$.

\subsection{Effect on Height and Total Dry Weight of Maize Seedlings}

The result from this study indicated that the height and the total dry weight of maize seedlings was affected by four kinds of biological organic fertilizers, while the effect was dependent on plant parameters, as well as the kinds of biological organic fertilizers and its concentration. In detail, compared to the control, there was a significant increase (range, $97.30 \%$ to $178.38 \%$ ) in the height of maize seedlings by organic fertilizer at $0.75,1.50$ and $2.25 \mathrm{~kg} / \mathrm{m}^{2}$, mushroom residue at 2.25 and $3.00 \mathrm{~kg} / \mathrm{m}^{2}$, biogas liquid at $300 \mathrm{~kg} / \mathrm{m}^{2}$, vegetable cake at $0.30 \mathrm{~kg} / \mathrm{m}^{2}$, while the height of maize seedlings was unaffected by all of the other treatments. Furthermore, the total dry weight of maize seedlings was unaffected by all of the treatments except the organic fertilizer at $1.50 \mathrm{~kg} / \mathrm{m}^{2}$, which cause a $16.67 \%$ increase in total dry weight of seedlings (Table 5).

Table 5. Effect of different biological organic fertilizers and chemical fertilizer on the height and total dry weight of maize seedlings.

\begin{tabular}{ccc}
\hline Treatments & Height & TDW \\
\hline COF $\left(0.75 \mathrm{~kg} / \mathrm{m}^{2}\right)$ & $25.98 \pm 1.73 \mathrm{ab}$ & $0.27 \pm 0.02 \mathrm{ab}$ \\
$\mathrm{COF}\left(1.50 \mathrm{~kg} / \mathrm{m}^{2}\right)$ & $23.95 \pm 2.74 \mathrm{ab}$ & $0.28 \pm 0.01 \mathrm{a}$ \\
$\mathrm{COF}\left(2.25 \mathrm{~kg} / \mathrm{m}^{2}\right)$ & $24.53 \pm 1.85 \mathrm{ab}$ & $0.27 \pm 0.02 \mathrm{ab}$ \\
$\mathrm{MR}\left(1.50 \mathrm{~kg} / \mathrm{m}^{2}\right)$ & $22.70 \pm 1.70 \mathrm{bc}$ & $0.26 \pm 0.02 \mathrm{bc}$ \\
MR $\left(2.25 \mathrm{~kg} / \mathrm{m}^{2}\right)$ & $26.40 \pm 1.60 \mathrm{a}$ & $0.26 \pm 0.01 \mathrm{bc}$ \\
MR $\left(3.00 \mathrm{~kg} / \mathrm{m}^{2}\right)$ & $25.80 \pm 3.20 \mathrm{ab}$ & $0.26 \pm 0.01 \mathrm{bc}$ \\
BL $\left(150 \mathrm{~kg} / \mathrm{m}^{2}\right)$ & $24.80 \pm 1.30 \mathrm{ab}$ & $0.25 \pm 0.01 \mathrm{bc}$ \\
$\mathrm{BL}\left(225 \mathrm{~kg} / \mathrm{m}^{2}\right)$ & $20.60 \pm 3.00 \mathrm{bc}$ & $0.24 \pm 0.01 \mathrm{bc}$ \\
BL $\left(300 \mathrm{~kg} / \mathrm{m}^{2}\right)$ & $24.20 \pm 1.60 \mathrm{ab}$ & $0.24 \pm 0.02 \mathrm{bc}$ \\
VC $\left(0.30 \mathrm{~kg} / \mathrm{m}^{2}\right)$ & $23.10 \pm 1.20 \mathrm{~b}$ & $0.25 \pm 0.01 \mathrm{bc}$ \\
VC $\left(0.60 \mathrm{~kg} / \mathrm{m}^{2}\right)$ & $21.90 \pm 3.60 \mathrm{bc}$ & $0.25 \pm 0.01 \mathrm{bc}$ \\
CCF $\left(37.50 \mathrm{~g} / \mathrm{m}^{2}\right)$ & $20.60 \pm 2.80 \mathrm{bc}$ & $0.25 \pm 0.01 \mathrm{bc}$ \\
Control & $19.90 \pm 2.00 \mathrm{c}$ & $0.24 \pm 0.02 \mathrm{bc}$ \\
\hline
\end{tabular}

COF-commercial organic fertilizer; MR-mushroom residue; BL—biogas liquid; VC—vegetable cake; CCFchemical compound fertilizer. TDW—-total dry weight. Values followed by different lowercase letters within the same column indicate a significant difference at $p<0.05$.

\subsection{Microbial Composition Determined by $16 S$ rRNA Amplicon Sequencing}

The composition of soil bacteria from each sample was determined using 16S rRNA amplicon sequencing. The results of this study showed that there was a variation in 
the community structure of soil bacteria among the samples at a genus level (Figure 2), which were dependent on the kind of amendments and their concentration. In general, no similar or same change in bacterial communities were observed for all of the amendments. However, this result also found that some specific bacteria may be associated with each amendment, for example, compared with the control, organic fertilizer at three different concentrations significantly increased the ratio of Rhizobiales and Alphaproteobacteria in the community structure. Indeed, the ratio of Alphaproteobacteria to the total soil bacteria was $1.57 \%, 1.19 \% \mathrm{~m}$ and $1.88 \%$ in organic fertilizer at concentrations of $0.75,1.50$, and $2.25 \mathrm{~kg} / \mathrm{m}^{2}$, respectively, while no Alphaproteobacteria was detected in the control. Furthermore, organic fertilizer at concentrations of $0.75,1.50$, and $2.25 \mathrm{~kg} / \mathrm{m}^{2}$ caused a $45.26 \%, 18.25 \%$, and $40.15 \%$ increase in the ratio of Rhizobiales, compared with the ratio of $1.30 \%$ in the control (Table 6).

Table 6. Effect of different organic fertilizers and chemical fertilizer on the microbial composition of newly reclaimed soil.

\begin{tabular}{|c|c|c|c|c|c|c|c|c|c|c|c|c|c|}
\hline \multirow{2}{*}{ Genus Name } & \multicolumn{13}{|c|}{ Percentage of Each Genus in Total Microbial Communicity (\%) } \\
\hline & A1 & A2 & A3 & B4 & B5 & B6 & $\mathrm{C7}$ & $\mathrm{C} 8$ & C9 & D10 & D11 & E12 & F13 \\
\hline Acidimicrobiales & 1.07 & 1.11 & & & & & 1.15 & 1.22 & 1.23 & 2.44 & 3.57 & 2.48 & 1.39 \\
\hline Actinobacteria & 1.94 & 1.92 & 1.93 & 2.23 & 2.06 & 1.96 & & & & & & & \\
\hline Acidobacteria_Gp1 & - & 1.12 & 1.39 & & & & & 1.44 & 1.60 & 2.82 & 3.54 & 2.33 & 1.42 \\
\hline Acidobacteria $\mathrm{Gp} 3$ & 1.35 & 1.43 & 1.26 & & & & 1.14 & 3.24 & 2.08 & 1.36 & - & 1.46 & 1.55 \\
\hline Actinomycetales & 2.33 & 3.39 & 2.39 & & & & 1.69 & 2.28 & 3.29 & 3.33 & 3.86 & 3.34 & 3.24 \\
\hline Alphaproteobacteria & 1.57 & 1.19 & 1.88 & & 1.17 & & & & & & & & \\
\hline Betaproteobacteria & 5.80 & 3.88 & 4.39 & 6.14 & 6.72 & 5.98 & 5.88 & 4.77 & 4.37 & 1.92 & 1.70 & 2.03 & 5.30 \\
\hline Bradyrhizobium & - & 1.04 & 1.08 & & & & & & & & & & \\
\hline candidate_division_WPS-1 & 3.35 & 2.88 & 3.79 & 4.85 & 3.58 & 2.06 & 3.46 & 4.48 & 4.96 & 5.40 & 5.48 & 5.55 & 3.84 \\
\hline candidate_division_WPS-2 & & & & & & & & & & 2.03 & 2.43 & 1.82 & - \\
\hline Chloroflexi & & 1.26 & & & & & 1.12 & 1.47 & 1.27 & 2.49 & 3.48 & 3.60 & 1.26 \\
\hline Gp1 & 6.48 & 5.43 & 5.61 & 1.69 & & & 8.67 & 12.94 & 14.68 & 10.17 & 7.17 & 9.16 & 12.34 \\
\hline $\mathrm{Gp} 2$ & & & & & & & & 1.18 & & 1.29 & & & \\
\hline $\mathrm{Gp3}$ & 1.48 & 1.34 & 1.02 & & & & 1.72 & 2.47 & 2.01 & & & & 1.79 \\
\hline $\mathrm{Gp} 4$ & & & & 2.96 & 4.13 & 7.16 & 1.49 & - & - & & & & - \\
\hline Gp6 & 4.20 & 2.62 & 3.15 & 4.63 & 6.80 & 9.12 & 3.25 & 1.20 & 1.07 & & & & 1.30 \\
\hline Gp7 & & 1.38 & & 1.32 & - & 1.00 & 1.83 & & & & & & 1.57 \\
\hline Gp16 & 1.59 & 1.08 & 1.16 & 1.35 & 1.52 & 2.52 & & & & & & & \\
\hline Gammaproteobacteria & 1.50 & 1.09 & 1.16 & & 1.11 & 1.35 & & & & - & 1.02 & & \\
\hline Gaiella & 1.82 & 2.76 & 2.23 & 1.24 & 1.48 & 1.32 & 2.01 & 2.09 & 1.97 & 2.24 & 3.07 & 2.74 & 2.41 \\
\hline Gemmatimonas & 6.46 & 7.26 & 10.14 & 12.25 & 9.02 & 6.15 & 7.49 & 5.72 & 6.09 & 5.24 & 4.54 & 4.48 & 6.51 \\
\hline Micromonosporaceae & 1.32 & & & 1.32 & 1.19 & 1.25 & & & & & & & \\
\hline Myxococcales & 2.89 & 1.66 & 2.53 & 2.34 & 2.59 & 2.66 & 1.91 & & 1.52 & 1.26 & 1.14 & 1.05 & 1.78 \\
\hline Planctomycetaceae & 1.10 & 1.03 & 1.19 & 1.51 & & & 1.84 & 1.66 & 1.33 & 1.13 & 2.21 & 2.04 & 1.55 \\
\hline Rhizobiales & 1.99 & 1.62 & 1.92 & 1.78 & 2.11 & 1.94 & 1.37 & 1.30 & 1.12 & 1.18 & 1.07 & 1.01 & 1.37 \\
\hline Rhodospirillales & 2.17 & 1.35 & 1.21 & 1.11 & 1.17 & - & 1.09 & 1.63 & 1.35 & 1.28 & - & 1.03 & 1.25 \\
\hline Sphingomonadaceae & 2.05 & 2.76 & 3.79 & 3.20 & 3.10 & 1.89 & 2.55 & 2.60 & 2.78 & 2.88 & 2.44 & 2.92 & 2.03 \\
\hline Sphingomonas & & & & 1.74 & 2.13 & 1.74 & & & & & & & \\
\hline Spartobacteria & & & & & & & 1.07 & & & & & & 1.11 \\
\hline Subdivision3 & 1.01 & 1.16 & 1.33 & 1.08 & 1.08 & 1.35 & 1.45 & 1.73 & & & & 1.03 & 1.07 \\
\hline Ktedonobacteria & & 1.53 & & & & & & 1.01 & 1.04 & 4.38 & 2.78 & 3.03 & \\
\hline Ktedonobacter & & 1.12 & & & & & & & 1.37 & & 1.42 & & \\
\hline Ktedonobacterales & 2.82 & 5.97 & 1.57 & & & & 4.45 & 5.63 & 8.08 & 10.08 & 6.15 & 9.35 & 5.28 \\
\hline Candidatus_Saccharibacteria & & 1.03 & 1.19 & & & & & & & 1.74 & 2.45 & 1.03 & \\
\hline Thermomonosporaceae & & 1.11 & & & & & & & & & 1.27 & & \\
\hline Xanthomonadaceae & 1.35 & & & & & & & & & & 1.40 & & \\
\hline Anaeromyxobacter & & & & & & & 1.17 & & & & & & \\
\hline Burkholderia & & & & & & & & 1.09 & & & & & \\
\hline Solirubrobacterales & & & & & & & & & & 1.10 & 1.03 & 1.20 & \\
\hline Pseudonocardiaceae & & & & & & & & & & & 1.15 & & \\
\hline Geodermatophilus & & & & & & & & & & & 1.38 & & \\
\hline Bacteria & 8.13 & 8.92 & 7.91 & 10.15 & 13.62 & 12.60 & 10.91 & 9.82 & 9.50 & 11.78 & 7.81 & 11.09 & 12.98 \\
\hline Others & 34.22 & 28.59 & 34.76 & 37.11 & 35.39 & 37.94 & 31.28 & 29.03 & 27.29 & 22.45 & 26.45 & 26.23 & 27.65 \\
\hline
\end{tabular}

A1-3: commercial organic fertilizer at $0.75,1.50$, and $2.2 .5 \mathrm{~kg} / \mathrm{m}^{2} ; \mathrm{B} 4-6:$ mushroom residue at $1.50,2.25$, and $3.00 \mathrm{~kg} / \mathrm{m}^{2} ; \mathrm{C} 7-9$ : biogas liquid at 150,225 , and $300 \mathrm{~kg} / \mathrm{m}^{2} ; \mathrm{D} 10-11$ : vegetable cake at 0.30 and $0.60 \mathrm{~kg} / \mathrm{m}^{2} ;$ E12: chemical compound fertilizer $\left(37.50 \mathrm{~g} / \mathrm{m}^{2}\right) ; \mathrm{F} 13:$ control.

\subsection{Isolation of the Representative Strains of P-Solubilizing Bacteria}

Fifteen P-solubilizing bacterial isolates were picked up from the NBRIP growth medium, which showed a clear halo with a diameter ranging from $4.60 \mathrm{~mm}$ to $9.35 \mathrm{~mm}$ (Figure 3 and Table 7). Among these isolates, four strains originated from organic fertilizer at $1.50 \mathrm{~kg} / \mathrm{m}^{2}$, two strains originated from organic fertilizer at $2.25 \mathrm{~kg} / \mathrm{m}^{2}$, one strain originated from mushroom residue at $3.00 \mathrm{~kg} / \mathrm{m}^{2}$, three strains originated from biogas liquid at $150 \mathrm{~kg} / \mathrm{m}^{2}$, two strains originated from biogas liquid at $225 \mathrm{~kg} / \mathrm{m}^{2}$, one strain 
originated from biogas liquid at $300 \mathrm{~kg} / \mathrm{m}^{2}$, one strain originated from vegetable cake at $0.30 \mathrm{~kg} / \mathrm{m}^{2}$, and one strain originated from vegetable cake at $0.60 \mathrm{~kg} / \mathrm{m}^{2}$. Furthermore, all of the strains, except strains 7-3, 7-8, and 10-4, showed an N-fixation ability, and strains 7-3 and 7-8 originated from the biogas liquid at $150 \mathrm{~kg} / \mathrm{m}^{2}$, while strain $10-4$ originated from vegetable cake at $0.30 \mathrm{~kg} / \mathrm{m}^{2}$ (Table 7 and Figure 4).

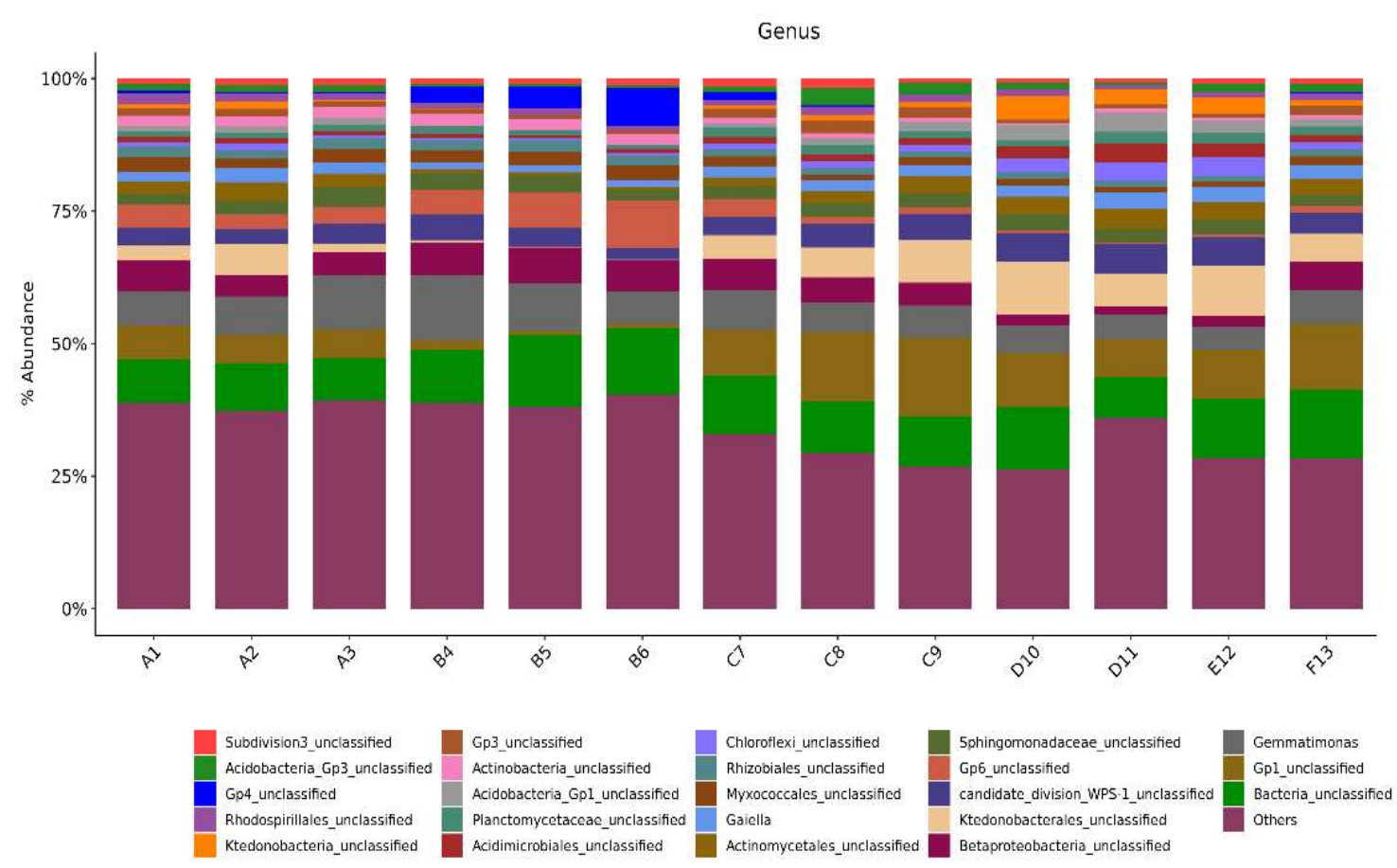

Figure 2. Change in microbial compositionat agenus level. A1-3: Commercial organic fertilizer at $0.75,1.50$, and $2.25 \mathrm{~kg} / \mathrm{m}^{2}$; B4-6: mushroom residue at 1.50, 2.25, and $3.00 \mathrm{~kg} / \mathrm{m}^{2} ; \mathrm{C} 7-9$ : biogas liquid at 150, 225, and $300 \mathrm{~kg} / \mathrm{m}^{2}$; D10-11: vegetable cake at 0.30 and $0.60 \mathrm{~kg} / \mathrm{m}^{2} ;$ E12: chemical compound fertilizer $\left(37.50 \mathrm{~g} / \mathrm{m}^{2}\right)$; F13: control.

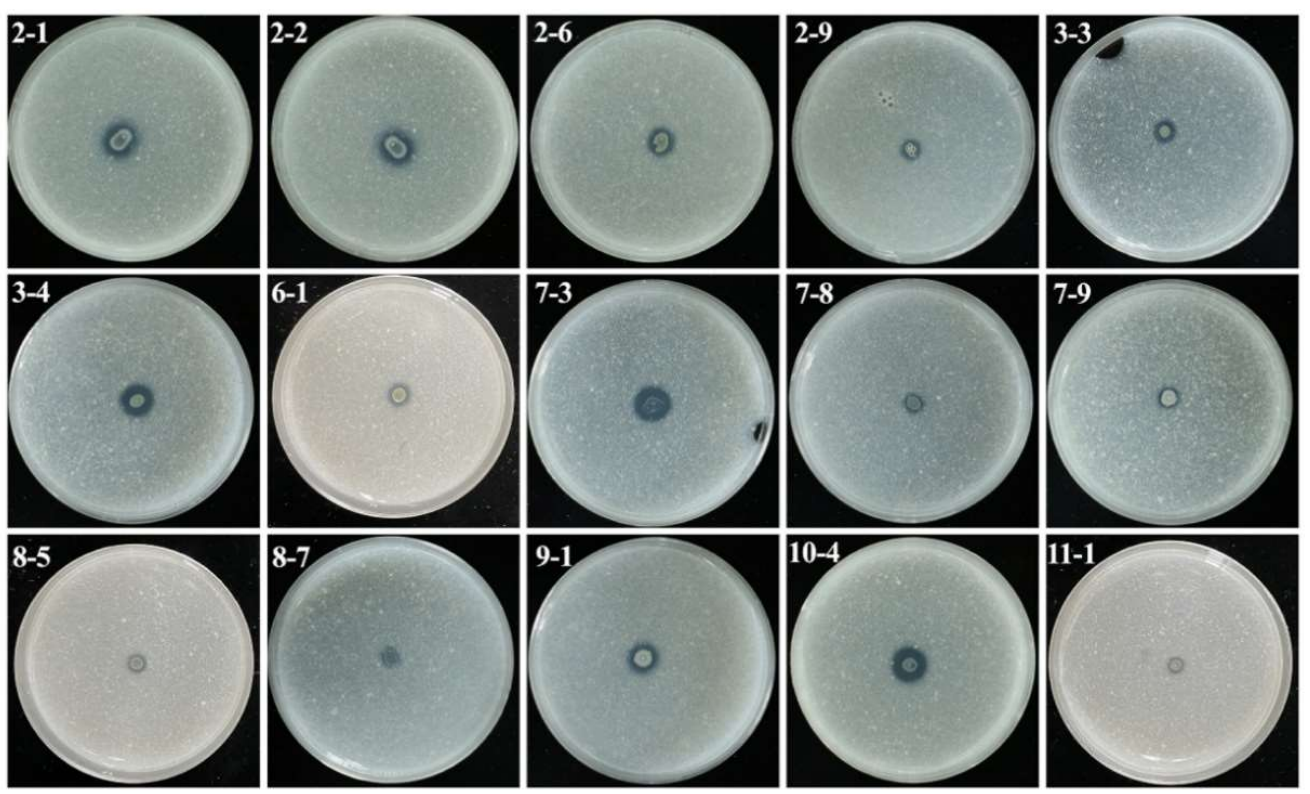

Figure 3. The phosphate solubilization ability of representative strains originating from the newly reclaimed land amendment with different organic fertilizers. 
Table 7. Representative strains of P-solubilization and N-fixation bacteria originating from the newly reclaimed land amendment with different organic fertilizers.

\begin{tabular}{cccc}
\hline Strains & Bacterial Origin & N-Fixation Ability & P-Solubilization Ability (mm) \\
\hline $2-1$ & COF $\left(1.50 \mathrm{~kg} / \mathrm{m}^{2}\right)$ & + & $8.97 \pm 1.24 \mathrm{a}$ \\
$2-2$ & $\mathrm{COF}\left(1.50 \mathrm{~kg} / \mathrm{m}^{2}\right)$ & + & $8.71 \pm 0.78 \mathrm{a}$ \\
$2-6$ & $\mathrm{COF}\left(1.50 \mathrm{~kg} / \mathrm{m}^{2}\right)$ & + & $6.52 \pm 0.95 \mathrm{bc}$ \\
$2-9$ & $\mathrm{COF}\left(1.50 \mathrm{~kg} / \mathrm{m}^{2}\right)$ & + & $4.67 \pm 0.78 \mathrm{~d}$ \\
$3-3$ & $\mathrm{COF}\left(2.25 \mathrm{~kg} / \mathrm{m}^{2}\right)$ & + & $5.68 \pm 0.65 \mathrm{~cd}$ \\
$3-4$ & $\mathrm{COF}\left(2.25 \mathrm{~kg} / \mathrm{m}^{2}\right)$ & + & $8.39 \pm 0.94 \mathrm{a}$ \\
$6-1$ & $\mathrm{MR}\left(3.00 \mathrm{~kg} / \mathrm{m}^{2}\right)$ & + & $6.86 \pm 0.63 \mathrm{~b}$ \\
$7-3$ & $\mathrm{BL}\left(150 \mathrm{~kg} / \mathrm{m}^{2}\right)$ & - & $7.02 \pm 2.35 \mathrm{~b}$ \\
$7-8$ & $\mathrm{BL}\left(150 \mathrm{~kg} / \mathrm{m}^{2}\right)$ & + & $5.16 \pm 0.63 \mathrm{~cd}$ \\
$7-9$ & $\mathrm{BL}\left(150 \mathrm{~kg} / \mathrm{m}^{2}\right)$ & + & $5.73 \pm 0.30 \mathrm{c}$ \\
$8-5$ & $\mathrm{BL}\left(225 \mathrm{~kg} / \mathrm{m}^{2}\right)$ & + & $4.86 \pm 0.23 \mathrm{~cd}$ \\
$8-7$ & $\mathrm{BL}\left(225 \mathrm{~kg} / \mathrm{m}^{2}\right)$ & - & $5.23 \pm 0.50 \mathrm{~cd}$ \\
$9-1$ & $\mathrm{BL}\left(300 \mathrm{~kg} / \mathrm{m}^{2}\right)$ & + & $7.11 \pm 0.94 \mathrm{~b}$ \\
$10-4$ & $\mathrm{VC}\left(0.30 \mathrm{~kg} / \mathrm{m}^{2}\right)$ & $9.35 \pm 0.53 \mathrm{a}$ \\
$11-1$ & $\mathrm{VC}\left(0.60 \mathrm{~kg} / \mathrm{m}^{2}\right)$ & $4.60 \pm 0.17 \mathrm{~d}$ \\
\hline
\end{tabular}

COF-commercial organic fertilizer; MR-mushroom residue; BL-biogas liquid; VC-vegetable cake. Values followed $\mathrm{b}$ different lowercase letters within the same column indicate significant difference at $p<0.05$.
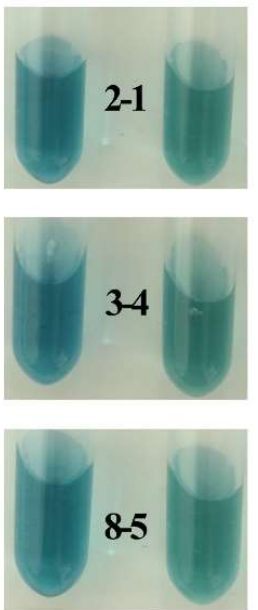

Treatment Control
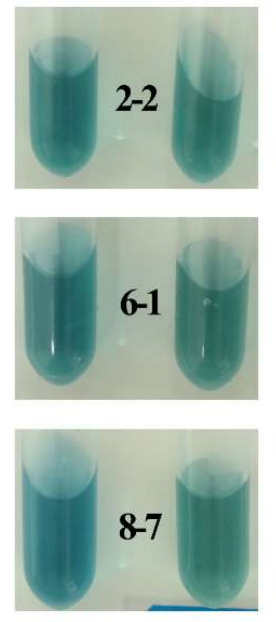

Treatment Control Treatment Control
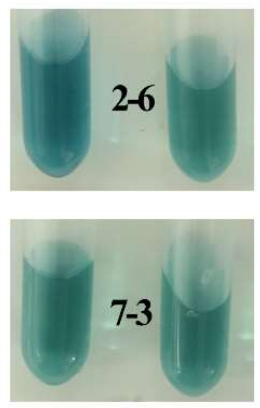
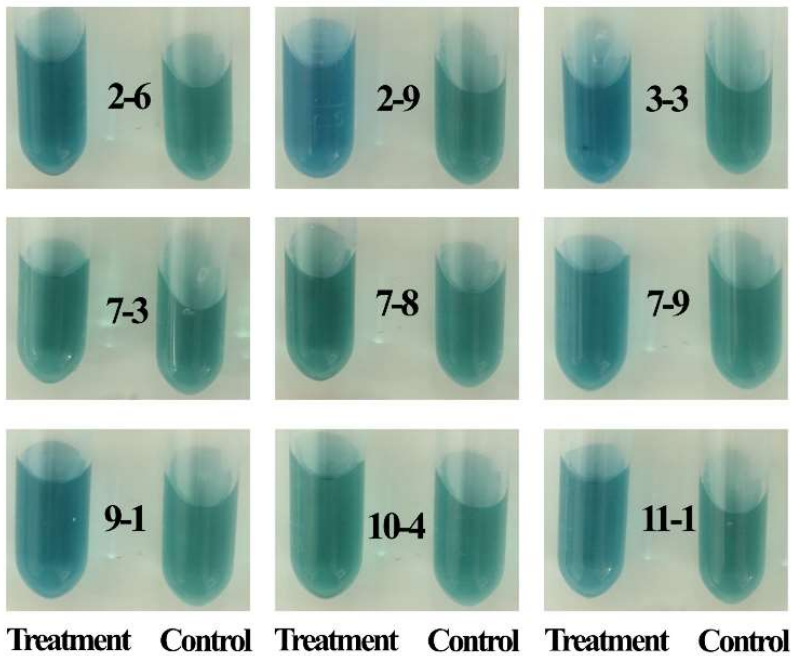

Figure 4. N-fixation ability of representative strains originated from the newly reclaimed land amendmentwith different organic fertilizers.

\subsection{Identification of P-Solubilization and N-Fixation Bacteria}

Representative isolates of P-solubilization and $\mathrm{N}$-fixation bacteria were picked up from the NBRIP growth medium, and were then further identified based on both the colony morphology observation and an analysis of the $16 \mathrm{~S}$ rDNA sequence. The results from this study were that strains 2-1 and 9-1 could be identified as Enterobacter hormaechei, with $99.8 \%$ and $99.9 \%$ sequence similarity, respectively. Strain $2-2$ could be identified as Enterobacter cloacae with $99.8 \%$ sequence similarity, and strains 2-6 and 2-9 could be identified as Pseudomonas putida, with $99.8 \%$ and $99.9 \%$ sequence similarity, respectively. Strain 3-3 could be identified as Pseudomonas oryzihabitans, with $99.8 \%$ sequence similarity, and strains 3-4, 6-1, and 8-7 could be identified as Pseudomonas fluorescens, with $99.8 \%, 99.8 \%$, and $99.9 \%$ sequence similarity, respectively. Strain 7-3 could be identified as Escherichia coli, with 99.8\% sequence similarity, and strains 7-8 and 11-1 could be identified as Pseudomonas poae, with $99.8 \%$ and $99.9 \%$ sequence similarity, respectively. Strains 7-9, 8-5, and 10-4 could be identified as Raoultella ornithinolytica, Pseudomonas qingdaonensis, and Ochrobactrum haematophilum, with 99.8\%, 99.8\%, and 99.9\% sequence similarity, respectively (Table 8). 
Table 8. Identification of representative isolates of P-solubilizing and N-fixation bacteria based on analysis of $16 \mathrm{~S}$ rDNA sequence.

\begin{tabular}{cccc}
\hline Strains & Bacterial Identity & Sequence Similarity (\%) & Accession Number \\
\hline $2-1$ & Enterobacter hormaechei & 99.65 & MW582664 \\
$2-2$ & Enterobacter cloacae & 99.51 & MW582665 \\
$2-6$ & Pseudomonas putida & 99.72 & MW582667 \\
$2-9$ & Pseudomonas putida & 99.65 & MW582668 \\
$3-3$ & Pseudomonas oryzihabitans & 99.65 & MW582669 \\
$3-4$ & Pseudomonas fluorescens & 99.65 & MW582670 \\
$6-1$ & Pseudomonas fluorescens & 99.72 & MW582671 \\
$7-3$ & Escherichia coli & 99.86 & MW582672 \\
$7-8$ & Pseudomonas poae & 99.51 & MW582674 \\
$7-9$ & Raoultella ornithinolytica & 99.79 & MW582675 \\
$8-5$ & Pseudomonas qingdaonensis & 99.86 & MW582677 \\
$8-7$ & Pseudomonas fluorescens & 99.72 & MW582678 \\
9-1 & Enterobacter hormaechei & 99.79 & MW582679 \\
$10-4$ & Ochrobactrum haematophilum & 99.64 & MW582680 \\
$11-1$ & Pseudomonas poae & 99.58 &
\end{tabular}

\section{Discussion}

Land development and reclamation is regarded as a good way to keep the balance system of occupation and compensation. However, the quality of most of the newly reclaimed land cannot meet the requirements of a high yield or even cultivation because of poor soil fertility and suitability for cultivation. In general, the overall quality of cultivated land has shown a declining trend; for example, the investigation into soil fertility and the quality of newly reclaimed land in the Lin'an and Yuhang District of Hangzhou, Zhejiang Province in recent years has shown that there are many problems in the newly reclaimed land, such as a low organic matter content; extremely low available phosphorus content; lack of most nutrients; and uncoordinated water, fertilizer, gas, and heat, and so on. In some cases, the production capacity of the newly reclaimed farmland is only $10-30 \%$ of the occupied farmland [1,2].

The productive capacity of the newly reclaimed land often needs 7-10 years of fertilization to basically reach the level of occupied cultivated land. In the actual production practice, we can improve the quality of newly reclaimed land by acidification adjustment, planting green manure, returning straw to field, comprehensive utilization of agricultural and animal husbandry wastes, using rural litter to make compost, and promoting the use of commercial organic fertilizer [7-13]. Indeed, the improvement of these measurements in soil quality may be mostly due to their increase in the content of soil organic matter. As is known, there are many factors affecting the soil quality of cultivated land, such as soil texture, structure, thickness, $\mathrm{OMC}, \mathrm{pH}$, cation exchange capacity, available phosphorus and potassium, and crop planting adaptability, as well as a series of physical, chemical, and biological properties. Among these factors, the content of soil organic matter is the basis to measure soil fertility.

China attaches great importance to the cultivation and improvement of cultivated land fertility. In the past 30 years, a lot of human and material resources have been invested into soil improvement. The soil nutrients of newly reclaimed land have been significantly improved, and the soil acidity has decreased significantly. It can be seen that choosing the right conditioner is the key to the success or failure of the efficient use of the new cultivated land. Organic fertilizer, used as an important measure, has been applied to improve the soil suitability of newly reclaimed land by increasing the content of the soil organic matter. In agreement with the results of this study, our previous greenhouse culture experiment also found that commercial organic fertilizer could comprehensively improve six soil physical properties of three kinds of newly cultivated lands, indicating that commercial organic fertilizers are ideal conditioners for newly reclaimed soil [3]. 
The results from this study indicate that the content of organic matter increased from all of the treatments, regardless of the organic and inorganic amendments. Although there were differential effects in the improvement of organic matter content among these organic amendments, including commercial organic fertilizer, mushroom residue, biogas liquid, and vegetable cake, the effects of organic amendments are in general better than those of inorganic amendments (commercial chemical fertilizer). The reason may be mainly due to the rich organic content of these organic amendments. The lack of organic matter is a common problem in newly reclaimed soil. Therefore, the supplement of an organic conditioner can make up for the deficiency of organic matter in improving the physical properties.

The results of this study indicate that the commercial organic fertilizer at three different concentrations had the greatest increase in the content of organic matter. In agreement with the results of this study, commercial organic fertilizer has been reported to be not only able to improve the content of organic matter, but also to improve the physical properties of soil, resulting in soil that can quickly become loose, a cultivation layer that becomes thicker, the ability to maintain fertilizer and water conservation is strengthened, the effective nutrients of soil are greatly improved, and the yield is significantly increased. In contrast, an irregular change was also found in some parameters such as the content of organic matter from the other organic fertilizers; for example, mushroom residue at $3.00 \mathrm{~kg} / \mathrm{m}^{2}$ showed a lower increase of OMC than that of mushroom residue at 1.50 and $2.25 \mathrm{~kg} / \mathrm{m}^{2}$, while biogas liquid at 225 and $300 \mathrm{~kg} / \mathrm{m}^{2}$ showed a lower increase than that of biogas liquid at $150 \mathrm{~kg} / \mathrm{m}^{2}$. These results indicate that the concentrations should be considered in the application of these soil amendments.

To our surprise, the OMCs of the mushroom residue at $3.00 \mathrm{~kg} / \mathrm{m}^{2}$ and biogas liquid at 225 and $300 \mathrm{~kg} / \mathrm{m}^{2}$ were lower than those of the chemical compound fertilizer, although all treatments increased the OMC compared with the control. This result indicates the complexity of the interaction between organic fertilizer and soil (or soil microbe), while organic fertilizers at a high concentration may have a weak even harmful effect on soil quality. On the other hand, this may also be because these soil amendments were not mixed well enough. Indeed, the commercial organic fertilizer used in the form of compost exhibited a great and stable effect in the improvement of the soil quality. Therefore, a formula should be developed for each organic fertilizer, which all showed great potential in the improvement of soil quality in this study.

Similar to the irregular changes in the content of organic matter, the available $\mathrm{P}$ decreased with the increase of concentrations of mushroom residue, while biogas liquid at $300 \mathrm{~kg} / \mathrm{m}^{2}$ showed a reduction in available P compared with that of biogas liquid at 150 and $225 \mathrm{~kg} / \mathrm{m}^{2}$. Furthermore, mushroom residue at $3.00 \mathrm{~kg} / \mathrm{m}^{2}$ showed a reduced increase in total $\mathrm{N}$ compared with that of mushroom residue at 1.50 and $2.25 \mathrm{~kg} / \mathrm{m}^{2}$, while mushroom residue at $1.50 \mathrm{~kg} / \mathrm{m}^{2}$ showed a greater increase in alkaline hydrolysis $\mathrm{N}$ compared with that of mushroom residue at 2.25 and $3.00 \mathrm{~kg} / \mathrm{m}^{2}$. In addition, biogas liquid at $300 \mathrm{~kg} / \mathrm{m}^{2}$ showed a reduced increase in alkaline hydrolysis $\mathrm{N}$ compared with that of biogas liquid at 150 and $225 \mathrm{~kg} / \mathrm{m}^{2}$.

The results of plate counting revealed that the number of total soil bacteria and phosphate-solubilizing bacteria was unaffected or increased with the organic and inorganic amendments compared with the control. However, there was no significant difference in the number of total soil bacteria and phosphate-solubilizing bacteria between the chemical compound fertilizer and different organic fertilizer treatments, except for the commercial organic fertilizer at $2.25 \mathrm{~kg} / \mathrm{m}^{2}$, which showed a greater increase in the total soil bacterial number. Similarly, an analysis of the total soil biomass revealed that the microbial biomass carbon was increased or unaffected by all of the organic and inorganic amendments. In addition, it was also observed that there was a difference in the change of the soil total biomass and the soil total bacterial number, which may be due to the difference in the methods used. 
In contrast with the results of microbial biomass carbon, microbial biomass nitrogen was increased or unaffected by four treatments, but was deceased by the other eight treatments compared with the control, while the change in microbial biomass nitrogen depended on the kind and concentration of the amendments. Indeed, microbial biomass nitrogen was decreased or unaffected with the increase in the concentrations of these soil amendments, except for biogas liquid at $225 \mathrm{~kg} / \mathrm{m}^{2}$, which showed a greater increase compared with that of the biogas liquid at $150 \mathrm{~kg} / \mathrm{m}^{2}$. The reduction in microbial biomass nitrogen may be, at least partially, because the total $\mathrm{N}$ in the soil environment of the newly reclaimed land is enough for the survival and growth of soil bacteria.

It can be inferred that the differential effect in the improvement of the above-mentioned soil quality parameters may be mainly attributed to the difference in the composition of these soil amendments. For example, the $\mathrm{pH}$ of newly reclaimed soil was significantly decreased by vegetable cake at two concentrations and the chemical fertilizer compared with the control, which may be due to the lower $\mathrm{pH}$ in the two soil amendments than that of the newly reclaimed soil. In contrast, the $\mathrm{pH}$ of the newly reclaimed soil was unaffected or increased by commercial organic fertilizer, mushroom residue, and biogas liquid, which can be well explained by the higher $\mathrm{pH}$ in these soil amendments than that of the newly reclaimed soil.

In this study, only commercial organic fertilizer at $1.50 \mathrm{~kg} / \mathrm{m}^{2}$ significantly increased the total dry weight of the maize, while the three biggest increases were all from commercial organic fertilizers. This may be partly due to the low nutritional requirements of maize, and the regular watering during the growth process, which provided sufficient conditions for plant growth. Obviously, compared with the other organic fertilizers, the effect of commercial organic fertilizer is greater and more stable, while its price is also cheap. Therefore, it can be suggested that the commercial organic fertilizer has a great potential for soil improvement because of these advantages.

The microbial community analysis displayed the trend of the main genera abundance distribution of each sample. This study revealed a change in the genus composition of the soil microbial community structure among the samples. In general, the change may depend on the kind of amendment and its concentration, while it seems that no similar or the same bacterial species were enriched by all of the amendments at different concentrations. Interestingly, the amendment's improvement of the soil quality may be justified by the change in the soil microbial community [32-34]. For example, compared with the control, commercial organic fertilizer enriched the Rhizobiales and Alphaproteobacteria, which has been reported to comprise several genera of nodule-inducing symbiotic bacteria associated with plant roots. Therefore, it can be inferred that organic fertilizer may improve the soil quality by enriching these soil bacteria in the newly cultivated land.

Compared with the traditional plate culture method, 16S rRNA amplicon sequencing gives a comprehensive analysis in the community composition of soil bacteria. Indeed, the non-culture method has the advantage of quicker results, less samples, and being less expensive, but it also has the disadvantage of being unable to know whether these soil bacteria are alive or dead. In contrast, the culture method in this study provides an alternate strategy for the analysis of the soil bacterial profiles by isolating the live bacteria and then focusing on the number of total bacteria and P-solubilizing bacteria. However, no P-solubilization bacteria were isolated in the treatments of the chemical fertilizer and the control, which is in contrast with the number of P-solubilization bacteria. This difference between the two experiments may be mainly because only colonies with clear halo were isolated and further identified in this study. It is well known that soil fertility is associated with bacterial richness; interestingly, an effective approach has been proposed in our recent study [26] to screen biofertilizer bacteria based on functional analysis and genome mining. Therefore, more attention should be paid to the function of these soil bacteria, such as their role in the improvement of the soil organic matter content. 


\section{Conclusions}

Overall, the result from this study indicate that the commercial organic fertilizer, mushroom residue, biogas liquid, and vegetable cake increased the OMC, which is regarded as the most significant soil quality index. This suggests that the soil amendments used in this study have great potential for improving the soil quality in newly reclaimed land. However, the effect of improvement differed among these soil amendments, while the greatest increase was achieved by the commercial organic fertilizer. Indeed, commercial organic fertilizers not only caused an increase in moisture contents $(9.35-16.35 \%)$, the $\mathrm{pH}$ (11.56-18.72\%), OMC (1.73-2.15 fold), available P (338.44-491.41\%), total N (36.80-48.14\%), alkaline hydrolysis $\mathrm{N}(95.32-128.34 \%)$, total bacterial numbers (92.57-178.38\%), and microbial biomass carbon (7.57-20.87 fold) of the newly reclaimed soil, but also improved the height $(20.35-30.55 \%)$ and total dry weight (12.50-16.67\%) of the maize seedlings in the pot experiment compared with the control. In conclusion, our results suggest that organic fertilizers, particularly commercial organic fertilizer, can be used as a good amendment for the newly reclaimed farmland.

Author Contributions: Conceptualization, X.L., Y.S., T.A., H.R.; Y.Y., Q.A., J.Y. and B.L.; methodology, X.L., Y.S. and T.A.; software, M.R.J., X.L., Y.S. and T.A.; validation, X.L., Y.S. and T.A.; formal analysis, X.L., Y.S., T.A. and Q.A.; investigation, X.L., M.R.J. and Y.S.; resources, X.L., H.R., M.R.J., Y.Y., Q.A., J.Y. and B.L.; data curation, X.L. and J.Y.; writing-original draft preparation, X.L., Y.S., T.A., H.R., Y.Y., Q.A., J.Y. and B.L.; writing-review and editing, T.A., Q.A., J.Y. and B.L.; visualization, T.A., Q.A., J.Y. and B.L.; supervision, Y.Y., J.Y. and B.L.; project administration, J.Y. and B.L.; funding acquisition, J.Y. and B.L. All authors have read and agreed to the published version of the manuscript.

Funding: This research was funded by the Key Research and Development Program of Zhejiang Province (2019C02035, 2017C02002, 2019C02006, and 2020C02006), the Natural Science Foundation of Zhejiang Province (LY19C010007 and LZ19C140002), the National Natural Science Foundation of China (31872017 and 32072472), the Shanghai Agriculture Applied Technology Development Program (2019-02-08-00-08-F01150), the Dabeinong Funds for Discipline Development and Talent Training in Zhejiang University, and the Fundamental Research Funds for the Central Universities.

Institutional Review Board Statement: Not applicable.

Informed Consent Statement: Not applicable.

Data Availability Statement: The nucleotide sequences generated in this study were deposited at: https:/ / www.ncbi.nlm.nih.gov/genbank/under the accession numbers MW582664-582680.

Conflicts of Interest: The authors declare no conflict of interest.

\section{References}

1. Hu, G.C.; Chen, D.H.; Huang, X.P.; Zhou, C.H.; Yu, G.R.; Pan, J.L. The research about balance system of farm land in occupation and supplement: A demonstration from Lin'ancity. J. Agric. 2014, 4, 112-115. (In Chinese)

2. Wang, Z.; Shen, Q.Y.; Shen, J.G.; Zhu, J.; Ma, W.H.; Yang, Y.M. Investigation on soil physical and chemical properties of new cultivated land in Yuhang District and improvement measures. Zhejiang Agric. Sci. 2017, 58, 1467-1470. (In Chinese)

3. Yan, J.L.; Zhang, M.K.; Wang, D.Z. Different amendments: Effect on soil physical properties of newly reclaimed land in low hilly region. Chin. Agric. Sci. Bull. 2021, 37, 67-73. (In Chinese)

4. Liu, Z.; Cao, S.L.; Sun, Z.H.; Wang, H.Y.; Qu, S.D.; Lei, N.; He, J.; Dong, Q.G. Tillage effects on soil properties and crop yield after land reclamation. Sci. Rep. 2021, 11, 4611. [CrossRef]

5. Zhu, Q.; Hu, Z.Q.; Liu, X.R.; Wu, Y.J. Topsoil alternatives selection for surface coal-mined land reclamation in Inner Mongolia, China: An experimental study. Int. J. Min. Reclam. Environ. 2021. [CrossRef]

6. Xu, Y.; Pu, L.J.; Zhang, R.S.; Zhu, M.; Zhang, M.; Bu, X.G.; Xie, X.F.; Wang, Y. Effects of agricultural reclamation on soil physicochemical properties in the mid-eastern coastal area of China. Land 2021, 10, 142. [CrossRef]

7. Rendana, M.; Idris, W.M.R.; Rahim, S.A.; Rahman, Z.A.; Lihan, T.; Jamil, H. Reclamation of acid sulphate soils in paddy cultivation area with organic amendments. Aims Agric. Food 2018, 3, 358-371. [CrossRef]

8. Bednik, M.; Medynska-Juraszek, A.; Dudek, M.; Kloc, S.; Kret, A.; Labaz, B.; Waroszewski, J. Wheat straw biochar and NPK fertilization efficiency in sandy soil reclamation. Agronomy 2020, 10, 496. [CrossRef]

9. Teixeira, R.S.; Souza, I.F.; Santos, R.S.; Gomes, L.C.; Borges, S.R.; Vergutz, L.; Silva, I.R. Impact of fertilization on cover crops and microbial community on a bauxite-mined soil undergoing reclamation. J. Plant Nutr. Soil Sci. 2019, 182, 515-523. [CrossRef] 
10. Watkinson, A.D.; Lock, A.S.; Beckett, P.J.; Spiers, G. Developing manufactured soils from industrial by-products for use as growth substrates in mine reclamation. Restor. Ecol. 2017, 25, 587-594. [CrossRef]

11. Merino, A.; Omil, B.; Fonturbel, M.T.; Vega, J.A.; Balboa, M.A. Reclamation of intensively managed soils in temperate regions by addition of wood bottom ash containing charcoal: SOM composition and microbial functional diversity. Appl. Soil Ecol. 2016, 100, 195-206. [CrossRef]

12. Krummelbein, J.; Raab, T. Development of soil physical parameters in agricultural reclamation after brown coal mining within the first four years. Soil Till Res. 2012, 125, 109-115. [CrossRef]

13. Drozdowski, B.L.; Naeth, M.A.; Wilkinson, S.R. Evaluation of substrate and amendment materials for soil reclamation at a diamond mine in the Northwest Territories, Canada. Can. J. Soil Sci. 2012, 92, 77-88. [CrossRef]

14. Su, Y.; Yu, M.; Xi, H.; Lv, J.L.; Ma, Z.H.; Kou, C.L.; Shen, A. Soil microbial community shifts with long-term of different straw return in wheat-corn rotation system. Sci. Rep. 2020, 10, 6360. [CrossRef] [PubMed]

15. Qi, L.; Zhou, P.; Yang, L.H.; Gao, M. Effects of land reclamation on the physical, chemical, and microbial quantity and enzyme activity properties of degraded agricultural soils. J. Soil. Sediment. 2020, 20, 973-981. [CrossRef]

16. Li, B.; Wang, X.; Chen, R.X.; Huangfu, W.G.; Xie, G.L. Antibacterial activity of chitosan solution against Xanthomonas pathogenic bacteria isolated from Euphorbia pulcherrima. Carbohyd. Polym. 2008, 72, 287-292. [CrossRef]

17. Nautiyal, C.S. An efficient microbiological growth medium for screening phosphate solubilizing microorganisms. FEMS Microbiol. Lett. 1999, 170, 265-270. [CrossRef]

18. Zhang, J.; Xie, Y.H.; Wei, Y.; Meng, H.S.; Cao, Y.Z.; Qin, J.M.; Hong, J.P. Effects of fertilisation on microbial communities in short-term coal mine reclamation. Soil Res. 2020, 58, 779-789. [CrossRef]

19. Brandt, J.; Albertsen, M. Investigation of fetection limits and the influence of DNA extraction and primer choice on the observed microbial communities in drinking water samples using 16SrRNA gene amplicon sequencing. Front. Microbiol. 2018, 9, 2140. [CrossRef]

20. Bolyen, E.; Rideout, J.R.; Dillon, M.R.; Bokulich, N.A.; Abnet, C.C.; Al-Ghalith, G.A.; Alexander, H.; Alm, E.J.; Arumugam, M.; Asnicar, F.; et al. Reproducible, interactive, scalable and extensible microbiome data science using QIIME 2. Nat. Biotechnol. 2019, 37, 852-857. [CrossRef] [PubMed]

21. Oksanen, J.; Blanchet, F.G.; Friendly, M.; Kindt, R.; Legendre, P.; McGlinn, D.; Minchin, P.R.; O’Hara, R.B.; Simpson, G.L.; Solymos, P.; et al. Vegan: Community Ecology Package. R Package Version 2.5-7. Available online: https://CRAN.R-project.org/package= vegan (accessed on 28 November 2020).

22. Wickham, H. ggplot2: Elegant Graphics for Data Analysis; Springer: New York, NY, USA, 2016.

23. Kolde, R. Pheatmap: Pretty Heatmaps. R Package Version 1.0.12. Available online: https://CRAN.R-project.org/package= pheatmap (accessed on 4 January 2019).

24. Yu, G.C.; Smith, D.K.; Zhu, H.C.; Guan, Y.; Lam, T.T.Y. GGTREE: An R package for visualization and annotation of phylogenetic trees with their covariates and other associated data. Methods Ecol. Evol. 2017, 8, 28-36. [CrossRef]

25. Callahan, B.J.; McMurdie, P.J.; Rosen, M.J.; Han, A.W.; Johnson, A.J.A.; Holmes, S.P. DADA2: High-resolution sample inference from Illumina amplicon data. Nat. Methods 2016, 13, 581-583. [CrossRef] [PubMed]

26. Ali, M.A.; Lou, Y.; Hafeez, R.; Li, X.; Hossain, A.; Xie, T.; Lin, L.; Li, B.; Yin, Y.; Yan, J.; et al. Function alanalysis and genome mining reveal high potential of biocontrol and plant growth promotion in nodule-inhabiting bacteria within Paenibacillus polymyxa complex. Front. Microbiol. 2021. [CrossRef]

27. Masum, M.M.I.; Liu, L.; Yang, M.; Hossain, M.M.; Siddiqa, M.M.; Supty, M.E.; Ogunyemi, A.H.; An, Q.; Li, B. Halotolerant bacteria belonging to operational group Bacillus amyloliquefaciens in biocontrol of the rice brown stripe pathogen Acidovorax oryzae. J. Appl. Microbiol. 2018, 125, 1852-1867. [CrossRef]

28. Ding, Y.; Wang, J.; Liu, Y.; Chen, S. Isolation and identification of nitrogen-fixing bacilli from plant rhizospheres in Beijing region. J. Appl. Microbiol. 2005, 99, 1271-1281. [CrossRef] [PubMed]

29. Liu, X.; Li, Q.; Li, Y.; Guan, G.; Chen, S. Paenibacillus strains with nitrogen fixation and multiple beneficial properties for promoting plant growth. Peer J. 2019, 7, e7445. [CrossRef]

30. Anand, R.; Grayston, S.; Chanway, C. N2-fixation and seedling growth promotion of lodgepole pine by endophytic Paenibacillus polymyxa. Microb. Ecol. 2013, 66, 369-374. [CrossRef]

31. Wang, T.S.; Xie, J.Y.; Wang, L.Y.; Chen, S.F. Paenibacillus maysiensis sp. nov., a nitrogen-fixing species isolated from the rhizosphere soil of maize. Curr. Microbiol. 2018, 75, 1267-1273. [CrossRef]

32. Wang, F.; Peng, W.T.; Zhang, B.; Cao, Y.; Zhao, J.; Cao, H. Succession of bacterial community composition in coastal agricultural soils along a 1000-year reclamation chronosequence in Hangzhou Bay, China. Ecol. Indicat. 2021, 121, 106972. [CrossRef]

33. Uzarowicz, L.; Wolinska, A.; Blonska, E.; Szafranek-Nakonieczna, A.; Kuzniar, A.; Slodczyk, Z.; Kwasowski, W. Technogenic soils (Technosols) developed from mine spoils containing Fe sulphides: Microbiological activity as an indicator of soil development following land reclamation. Appl. Soil Ecol. 2021, 156, 103699. [CrossRef]

34. Wang, X.Y.; Li, Y.; Wei, Y.; Meng, H.S.; Cao, Y.Z.; Lead, J.R.; Hong, J.P. Effects of fertilization and reclamation time on soil bacterial communities in coal mining subsidence areas. Sci. Total Environ. 2020, 739, 139882. [CrossRef] [PubMed] 